УДК 341.66:343.132

DOI https://doi.org/10.32837/pyuv.v2i4(29).465

\author{
С. А. Путілова \\ orcid.org/0000-0002-8289-4727 \\ студентка магістратури \\ Навчально-наукового інституту заочного та дистаниійного навчання \\ Національної акаделії внутрішніх справ
}

\title{
ПРОЦЕСУАЛЬНИЙ ПОРЯДОК ВИКОНАННЯ ЗАПИТУ (ДОРУЧЕННЯ) ПРО МІЖНАРОДНО-ПРАВОВУ ДОПОМОГУ НА ТЕРИТОРІЇ УКРАЇНИ
}

Постановка проблеми. Належне визначення процесуального порядку виконання запиту (доручення) про міжнародно-правову допомогу на території України є одним із найскладніших та водночас вкрай важливих питань у сфері національного кримінального процесу. На цей час чинне кримінальне процесуальне законодавство не повною мірою відображає зміст багатоаспектної сфери міжнародної взаємодії, а також співробітництва між уповноваженими органами держави 3 питань виконання запитів про міжнародноправову допомогу на території України.

Актуальність теми дослідження. Сучасна національна система кримінальної юстиції перебуває на стадії реформування і приведення у відповідність до європейських та світових стандартів у питаннях забезпечення прав та свобод людини й громадянина. Цей довготривалий та фундаментальний процес передбачає внесення суттєвих змін до чинних нормативних актів, що регулюють функціонування сфери національного кримінального судочинства. Однак на цей час, попри вже наявні суттєві зміни в чинному кримінальному процесуальному законодавстві, залишаються не повною мірою врегульовані питання щодо належного визначення порядку виконання запиту (доручення) про міжнародно-правову допомогу на території нашої держави. Вирішення цього питання позитивним чином впливатиме на наявний правовий механізм функціонування сфери міжнародної взаємодії в контексті кримінальної процесуальної діяльності 3 належним дотриманням прав й свобод людини та громадянина, а також дотримання інтересів держави як суб'єкта міжнародних правовідносин.

Стан дослідження. Питання, пов' язані з дослідженням порядку міжнародної взаємодії в сфері кримінального процесу, досліджувалися такими науковцями, як Ю.М. Грошевий, М.I. Карпенко, А.В. Підгородинська, В.В. Сердюк, М.І. Смирнов, В.Я. Тацій, А.Р. Туманянц, Ю.М. Чорноус, О.О. Швець та інші.

Метою статті $€$ аналіз теоретичних положень щодо визначення ключових сутнісних критеріїв процесуального порядку виконання запиту (доручення) про міжнародно-правову допомогу на території України та обгрунтування власної авторської точки зори щодо окремих нормативних елементів цієї сфери кримінальної процесуальної діяльності.

Виклад основного матеріалу. Міжнародноправова взаємодія між державами є невіддільною частиною співпраці між окремими країнами на міжнародному рівні. Тісна взаємодія між державами у правовій сфері загалом та кримінальній процесуальній зокрема є одним 3 провідних напрямів вироблення практики протидії та попередження міжнародної злочинності. Стала взаємодія між державами в цьому напрямі створює міцне підгрунтя не лише для створення належної правової бази в цьому напрямі, а й дозволяє виробити належну практику та утворити дієвий механізм міждержавної взаємодії. Все це є необхідним в умовах глобалізації сучасного світу, який, попри наявність низки позитивних факторів, має й негативні, зокрема високий рівень транснаціональної злочинності. В таких реаліях, вочевидь, є зрозумілою ініціатива на міждержавному рівні щодо тісної співпраці з питань, пов'язаних з розслідуванням злочинних дій з метою якомога швидкого їх розкриття.

Визначаючи сутність міжнародної співпраці в сфрері розслідування злочинів, M.I. Смірнов зазначає, що правова допомога під час кримінального провадження є однією з форм міжнародного співробітництва і його пріоритетним напрямом. Цілями міжнародного співробітництва є забезпечення законних прав та інтересів громадян і юридичних осіб, сприяння ефективному відправленню правосуддя, боротьба зі злочинністю. Міжнародне співробітництво у сфері кримінального судочинства, на думку автора, можна визначити як взаємодію слідчого, прокурора і суду відповідно до вимог кримінального процесуального законодавства у порядку і на умовах, передбачених міжнародними договорами України або на основі взаємності, погоджену з компетентними органами і посадовими особами іноземних держав або міжнародних організацій [1, с. 188].

Загалом погоджуючись 3 автором щодо ключового вектору функціонування системи міжнародного співробітництва в сфері боротьби 
3 транснаціональної злочинності, слід наголосити, що звуження сфери міжнародної співпраці до взаємодії між слідчими, прокурорами та судами було б не зовсім коректним ствердженням. На наше переконання, сфера міжнародної взаємодії значно ширша, ніж відповідні приватні контакти окремих представників правоохоронних та судових систем окремих держав. Міжнародна взаємодія - це набагато змістовна та комплексна робота, що провадиться на міждержавному рівні iз залученням передусім як високопосадовців органів державної влади, так і представників правоохоронних органів та судової влади. Звісно, важливість участі цих суб'єктів у сфері ефективної взаємодії щодо боротьби та протидії міжнародній злочинності важко переоцінити, проте вони виконують все ж прикладну функцію, а «повістку дня» та ключові аспекти у вказаній сфері міжнародної співпраці формують інші суб'єкти, які, фактично реалізуючи політику держави, виступають від їі представниками на найвищому міждержавному рівні відносин.

У контексті зазначеного слід погодитися з M.I. Карпенко та О.О. Швець, які зосереджують увагу на важливих умовах, за яких можлива взаємодія між державами в напрямі розслідування злочинів. Отже, на думку авторів, це можливо у випадках, коли обвинувачений чи засуджений у кримінальному провадженні, порушеному на території однієї держави, переховується на території іншої держави, або коли свідки чи інші учасники кримінального судочинства, чи певні документи, що мають значення для справи, знаходяться не на території держави, на якій розслідується або розглядається кримінальне провадження. 3 метою виконання завдань кримінального процесу держави звертаються одна до одної за допомогою про розшук обвинуваченого або підозрюваного, його затримання або взяття під варту, а також про його видачу з метою залучення до кримінальної відповідальності та про вчинення слідчих чи інших процесуальних дій, без яких неможливі досудове розслідування, судовий розгляд або виконання вироку суду [2, с. 57].

Досліджуючи вказане питання, Ю.М. Грошевий зазначає, що в чинному КПК питання регулювання міжнародного співробітництва унормовані розділом IX «Міжнародне співробітництво під час кримінального провадження», в якому отримала свою кодифікацію досить складна та малознайома широкому колу вчених та практиків сфера процесуальної діяльності, яка, до речі, функціонує на стику декількох галузей права: кримінального, кримінального процесуального та міжнародного. Адже все частіше в процесі досудового розслідування та судового розгляду кримінальних проваджень національні уповноважені органи однієї країни запитують допомогу в іншої щодо надання, зокрема, речових доказів, забезпечення показань експертів та свідків, здійснення екстрадиції обвинувачених або видачі засуджених [3, с. 724]. Науковець наголошує, що надання міжнародної правової допомоги може включати здійснення таких традиційних заходів, як провадження обшуків, оглядів, вилучення та передача речових доказів, проведення експертиз, вручення документів, допит свідків, обвинувачених, експертів та інших осіб, надання відомостей про судимість особи та про обвинувальні висновки щодо неї, складання та пересилка документів, розшук та видача осіб, які вчинили злочини, визнання та виконання вироків тощо [3, с. 737].

Досліджуючи питання правової основи міжнародного співробітництва у розслідуванні злочинів, Ю.М. Чорноус справедливо наголошує, що правовою основою міжнародного співробітництва українських правоохоронних органів з відповідними органами іноземних держав є ратифіковані Верховою Радою України конвенції Організації Об’єднаних Націй, Ради Європи, рішення Ради глав держав і Ради глав урядів СНД, міжнародні багатосторонні і двосторонні договори держави, угоди і рішення таких органів координації взаємодії з партнерами із СНД, як Рада міністрів внутрішніх справ, Рада керівників органів безпеки та спеціальних служб та інші, а також договори та угоди міжвідомчого характеру. Міжнародне співробітництво у сфері кримінального судочинства без національного законодавства здійснюватися не може, адже воно є його підгрунтям та рушійною силою [4, с. 218].

Наведені науковцями напрями взаємодії між державами в сфері розслідування злочинів додатковий раз підтверджують комплексність цього різновиду міждержавних відносин. За цих умов $€$ можливим виконання будь-якого різновиду слідчої (розшукової), а рівно й процесуальної дії в межах здійснення кримінального провадження. Невіддільною частиною цього є виконання запитів (доручень) про міжнародно-правову допомогу на території України. Цей різновид міждержавної діяльності врегульований главою 43 КПК України (Міжнародна правова допомога при проведенні процесуальних дій). Специфікою норм зазначеної глави КПК України та взагалі розділу IX (Міжнародне співробітництво під час кримінального провадження) [5] є те, що вказані норми фактично відображають собою зміст та логіку чинного КПК України із використанням положень міжнародних документів, які регламентують сферу міждержавної взаємодії в контексті розслідування злочинів.

Такий нормативний симбіоз відповідним чином впливає на фактор сприйняття цих норм, які в окремих випадках дещо відрізняються від «буденних» формулювань та визначень, які 
містяться в інших розділах КПК України. Враховуючи фактор міжгалузевості зазначених норм КПК України перед законодавцем, під час створення КПК стояла непроста задача якомога коректного збалансування норм та положень КПК 3 тим, щоб уповноважені державою суб'єкти, які провадять досудове розслідування та судовий розгляд кримінальних проваджень, діяли з найбільшою ефективністю під час розслідування злочинів у сфері міжнародної взаємодії, у тому числі під час виконання запитів (доручень) про міжнародно-правову допомогу на території України.

Аналіз окремих чинних кримінальних процесуальних норм, визначених у КПК України, які регламентують порядок виконання запитів (доручень) про міжнародно-правову допомогу на території нашої держави, як на наш погляд, не є досконалими або не можуть сприйматися однозначно, що не кращим чином вливає на сприйняття підходу законодавця до урегулювання вкрай важливої сфери міждержавної взаємодії в сфері розкриття злочинів. Отже, передусім доцільно звернути увагу на регламентацію законодавцем положення ст. 548 КПК України (Запит про міжнародне співробітництво), а саме ч. 5 цієї норми. Відповідно до цієї частини статті КПК України уповноважений (центральний) орган України може прийняти до розгляду запит, який надійшов від запитуючої сторони електронним, факсимільним або іншим засобом зв'язку. Виконання такого запиту здійснюється винятково за умови підтвердження надіслання або передачі його оригіналу. Направлення компетентному органу іноземної держави матеріалів виконання запиту можливе тільки після отримання українською стороною оригіналу запиту [5].

Наведене положення викликає досить подвійне особисте сприйняття фактору регламентації міжнародної взаємодії в сфері виконання запитів про міжнародне співробітництво. Відповідно до ч. 5 ст. 548 КПК України [5], з одного боку, уповноваженому органу нашої держави цілком надається можливість прийняти до розгляду запит, який надійшов від запитуючої сторони електронним, факсимільним або іншим засобом зв'язку. Виконання такого запиту здійснюється винятково за умови підтвердження надіслання або передачі його оригіналу. В такому разі, як вважаємо, законодавці дійсно зробили крок до оптимізації міжнародної взаємодії в сфері розкриття злочинів, не лише дозволивши уповноваженому органу прийняти до розгляду електронний та/або факсимільний запит (доручення) про міжнародно-правову допомогу, а й передбачивши фактичну можливість оперативного реагування на неї навіть за відсутності безпосередньо документального запиту. Ініціацією діяльності уповноваженого органу України в такому разі може виступати лише факт підтвердження надіслання або передачі його оригіналу. 3 цього приводу позиція законодавця є вельми слушною, проте використання в законі припущення «може», як варіативність діяльності уповноваженого органу щодо реагування на запит (доручення) про міжнародно-правову допомогу, сприймається дещо неоднозначно.

Так, відповідно до глави 42 КПК України міжнародне співробітництво під час кримінального провадження здійснюється на підставі міжнародних договорів або за використанням засади взаємності між державами. У разі укладеної угоди між державами щодо подібного міжнародного співробітництва ця процедурність відповідним чином оговорюється та врегульовується сторонами. Попри вже укладену угоду міждержавного співробітництва, між такими державами також виникають певні довірчі відносини. Це відповідним чином покладає на сторони договору, окрім нормативного, ще й моральне зобов'язання щодо виконання його умов. Спираючись на це, на наше переконання, законодавець й відобразив в ч. 5 ст. 548 КПК України можливість процесуального реагування на запит (доручення) про міжнародно-правову допомогу у разі надходження, наприклад, електронної його версії та за підтвердження факту його надіслання [5]. При цьому припущення «може» фактично переводить фактор реагування на подібні запити у сферу дискреційності. За цих умов фактично від власного розсуду уповноваженого органу нашої держави залежатиме факт прийняття до розгляду чи відхилення подібного запиту.

Таке формулювання в КПК України фактору реагування на міжнародні запити є вельми неоднозначним, враховуючи фактор довірчих відносин між державами, які фактично відображаються в угоді про міжнародне співробітництво. На наше переконання, це припущення є зайвим у разі реагування на запити від держав, з якими вже укладено угоду про міжнародне співробітництво. Вважаємо, що припущення «може» варто залишити у вказаній нормі КПК України для реагування на міжнародні запити (доручення), які надійшли від держав, з якими ще не укладено міжнародного договору про взаємодію, а подібне співробітництво фактично здійснюється лише на підставі засади взаємності.

Окремо слід також звернути увагу на положення ч. 5 ст. 548 КПК України [5] в контексті надсилання відповіді на міжнародні запити (доручення). Законодавець є вельми категоричним в цьому разі та зазначає таке: направлення компетентному органу іноземної держави матеріалів виконання запиту можливе тільки після отримання українською стороною оригіналу запиту. Таке формулювання порядку надання відповіді міжнародні запити (доручення) також сприймається доволі неоднозначно. На цей час в умовах 
глобалізованої електронізації майже всіх сфер діяльності держав та надання пріоритету саме електронним та інтернет-засобам зв'язку перед класичними засобами спілкування та взаємодії (враховуючи стандартне листування) надання в законі пріоритетного значення саме класичним засобам зв'язку перед сучасними електронними виглядає дещо застарілим положенням. При цьому сучасні засоби захисту електронної інформації та підтвердження її аутентичності, оригінальності тощо цілком дозволяють обходитися взагалі без «паперової кореспонденції».

На жаль, надання пріоритетного значення сучасним електронним засобам зв'язку перед стандартними та фактично застарілими засобами взаємодії в межах регулювання міждержавних відносин щодо виконання міжнародних запитів (доручень), скоріш за все, досить не скоро знайде своє відображення в межах КПК України. А тому відповідно до ст. 558 КПК України [5] уповноважений орган вимушений чекати «отримання українською стороною оригіналу запиту" 3 тим, щоб надати відповідь на раніше отриману електронну версію цього ж запиту. Ця категоричність також виглядає досить нелогічною за умов, якщо між державами вже укладено угоду про міждержавне співробітництво в цій сфері. Тим більше, якщо з такою державою вже неодноразово здійснювався подібний «обмін» важливою в кримінальному процесуальному сенсі інформацією, то порядність такої сторони не викликає жодних запитань. Однак, знов таки, законодавець не робить щодо цього ніяких припущень та не передбачає жодної варіативності дій щодо цього.

Не важко спрогнозувати, що банальне затягування видачі іноземній державі процесуально важливої для неї інформації в сфері розслідування транснаціональної злочинності може негативним чином впливати на все розслідування, ставлячи під загрозу його ефективність. При цьому причиною цього може бути банальне очікування уповноваженим органом нашої держави оригіналу запиту задля того, щоб врешті-решт надати іншій стороні важливу кримінальну процесуальну інформацію. На наше переконання, це положення в КПК України потребує відповідного змінення та поповнення його відповідною варіативністю дії уповноваженого органу з наданням пріоритету електронним засобам зв'язку з тим, щоб якомога скоріше реагувати на міжнародні запити та вчасно надавати на них належні відповіді.

Чинну редакцію ч. 5 ст. 558 КПК України [5] щодо взаємодії між державами та реагування на запити (доручення) про міжнародно-правову до- помогу на території нашої держави та надання відповідної інформації за ними доцільно залишити лише для випадків, коли подібні запити надходять від держав, з якими не укладено угоди про міжнародне співробітництво та які вже порушували засаду взаємності під час взаємодії з питань, пов'язаних з розслідуванням злочинів на міждержавному рівні.

Висновки. Підсумовуючи вищевикладене, слід зазначити, що сфера міждержавної взаємодії щодо розкриття злочинів є вкрай важливим сегментом міждержавних відносин. Це твердження набуває особливої актуальності в умовах глобалізації сучасного світу, що, відповідно, впливає на збільшення показників транснаціональної злочинності. За цих умов оперативна взаємодія між державами щодо протидії та попередження злочинності може стати тим самим важливим форпостом на шляху зростання показників транснаціональної злочинності. Одним з обов'язкових та необхідних факторів ефективної взаємодії між державами виступає належне нормативне визначення подібних міждержавних відносин. Цей аспект без жодних сумнівів стосується й сфери внутрішнього законодавства кожної з держав сторін подібних угод та, відповідно, учасників міждержавних відносин у сфері взаємодії щодо розкриття злочинів. У контексті зазначеного вітчизняний законодавець має оперативно реагувати на зміни в кон'юнктурі розвитку сучасного світу та специфіки міждержавних відносин, які також мають урегульовуватись 3 урахуванням вимог сьогодення, що сприятиме якомога ефективній взаємодії між державами як у сфері протидії та боротьби зі злочинністю загалом, так і в кримінальній процесуальній сфері зокрема щодо вирішення питань, пов'язаних з виконанням запитів (доручень) про міжнародно-правову допомогу на території нашої держави.

\section{Jimepamypa}

1. Смирнов M.I. Сутність і правова природа міжнародного співробітництва держав у сфері кримінального процесу. Проблеми правознавства та правоохоронної діяльності: зб. наук. пр. 2004. № 1. С. 187-196.

2. Карпенко M.I. Міжнародне співробітництво у кримінальному провадженні. Юридична наука. 2013. № 8. С. 56-68.

3. Грошевий Ю.М. Кримінальний процес : підручник. Харків : Право, 2013. $824 \mathrm{c.}$

4. Чорноус Ю.М. Правова основа міжнародного співробітництва у розслідуванні злочинів. Вісник Луганського державного університету внутрішніх справ імені Е.О. Дідоренка. 2010. № 1. С. 217-225.

5. Кримінальний процесуальний кодекс України від 13.04.2012 № 4651-VI. Голос України. 2012. № 90-91. 


\section{Анотація}

Путілова С. А. Процесуальний порядок виконання запиту (доручення) про міжнародно-правову допомогу на території України. - Стаття.

У статті розглянуто окремі аспекти кримінального процесуального порядку виконання запиту про міжнародно-правову допомогу на території України. Розглянуто ключові критерії нормативного врегулювання кримінальної процесуальної процедури виконання запиту про міжнародно-правову допомогу. Наголошено на важливості дотримання збалансованого підходу із дотриманням прав та інтересів людини й громадянина, а також інтересів держави під час вирішення питання щодо виконання запиту (доручення) про міжнародно-правову допомогу. Зосереджено увагу важливості вчасної оптимізації чинних кримінальних процесуальних норм, що регулюють питання у сфері міжнародної взаємодії в межах кримінального провадження. Зроблено висновок, що сфера міждержавної взаємодії щодо розкриття злочинів є вкрай важливим сегментом міждержавних відносин. Це твердження набуває особливої актуальності в умовах глобалізації сучасного світу, що, відповідно, впливає на збільшення показників транснаціональної злочинності. За цих умов оперативна взаємодія між державами щодо протидії та попередженню злочинності може стати тим самим важливим форпостом на шляху зростання показників транснаціональної злочинності. Одним з обов'язкових та необхідних факторів ефективної взаємодії між державами виступає належне нормативне визначення подібних міждержавних відносин. Цей аспект, без жодних сумнівів, стосується й сфери внутрішнього законодавства кожної з держав сторін подібних угод та, відповідно, учасників міждержавних відносин у сфері взаємодії щодо розкриття злочинів. У контексті зазначеного вітчизняний законодавець має оперативно реагувати на зміни в кон'юнктурі розвитку сучасного світу та специфіки міждержавних відносин, які також мають урегульовуватись з урахуванням вимог сьогодення, що сприятиме якомога ефективній взаємодії між державами як у сфері протидії та боротьби зі злочинністю загалом, так і в кримінальній процесуальній сфері зокрема щодо вирішення питань, пов’язаних з виконанням запитів (доручень) про міжнародно-правову допомогу на території нашої держави.

Ключові слова: міжнародна взаємодія, запит про міжнародно-правову допомогу, удосконалення законодавства, поліпшення взаємодії між виконавцями запиту про міжнародно-правову допомогу, оптимізація сфери кримінальної процесуальної діяльності з виконання запитів про міжнародно-правову допомогу.

\section{Summary}

Putilova S. A. Procedural order of request execution (appointment) on the international and legal assistance in Ukraine. - Article.

The article deals with some aspects of the criminal procedural order for fulfilling the request for international legal assistance in Ukraine. The key criteria for regulating the criminal procedure of the request for international legal assistance are considered. The importance of adhering to a balanced approach with respect for the rights and interests of the individual and the citizen, as well as the interests of the state, is emphasized when deciding on the fulfillment of a request for international legal assistance. The importance of timely optimization of the existing criminal procedural rules governing issues in the sphere of international cooperation within the framework of criminal proceedings is focused. It is concluded that the sphere of interstate cooperation in relation to the disclosure of crimes is an extremely important segment of interstate relations. This statement is of particular relevance in the context of the globalization of the modern world, which accordingly influences the increase in transnational crime rates. Under these conditions, operational interaction between States on combating and preventing crime can become an important outpost for transnational crime. One of the necessary and necessary factors for effective interaction between states is the proper regulatory definition of such interstate relations. This aspect undoubtedly applies to the scope of the domestic legislation of each of the States Parties to such agreements and, accordingly, to the participants of interstate relations in the sphere of cooperation in relation to crime detection. In this context, the domestic legislator should respond promptly to changes in the current world development situation and the specifics of interstate relations, which should also be adjusted to the requirements of today, which will facilitate the most effective interaction between the states, both in the sphere of combating and crime in general, in particular, in the criminal procedural sphere to resolve issues related to the execution of requests (orders) for international legal assistance in the territory of our country.

Key words: international cooperation, request for international legal assistance, improvement of legislation, improvement of interaction between executors of the request for international legal assistance, optimization of the sphere of criminal procedural activity for the execution of requests for international legal assistance. 